\title{
Growth, flowering and fruiting in tomatoes in relation to temperature, cycocel and $\mathrm{GA}^{1}$
}

\author{
A. A. Abdalla and K. Verkerk \\ Department of Horticulture, Faculty of Agriculture, University of Khartoum, Sudan \\ Department of Horticulture, Agricultural University, Wageningen, the Netherlands
}

Received 22 September 1969

\section{Summary}

In conditions of high temperature, a covering tomato vine is desirable for protection of fruits from sun burn.

Increasing the carrying capacity of trusses by reducing losses resulting from flower dropping and failure of fruit set is equally important. The effects of the growth retardant cycocel (CCC) and GA on plants grown at high temperatures of $35^{\circ} \mathrm{C}$ day and $25^{\circ} \mathrm{C}$ night $(12 \mathrm{~h}+12 \mathrm{~h})$ and normal temperatures of $22^{\circ} \mathrm{C}$ day and $18^{\circ} \mathrm{C}$ night, in relation to growth, flowering and fruiting were investigated. CCC retards stem growth at both temperatures, but the plants at the high temperature resume normal growth rate sooner. Applied to soil at the start of flowering, CCC reduces flower drop, increases fruit-set and development, and reduces the competitive restriction of fruits in the first truss in plants at the high temperature. At the normal temperature no $\mathrm{CCC}$ effects were clear. Plants treated with $\mathrm{CCC}$ accumulate a higher tissue nitrogen level and their vine remains dark-green for a long period.

GA increased fruit set at the high temperatures, but the fruits developed were small and seedless. It also accelerated fruit ripening at both temperatures.

At the high temperature fruits were obtained only after hand pollination with fresh pollen from plants at the normal temperature.

\section{Introduction}

Tomato plants in high temperature conditions grow fast, develop long thin branches with a decidedly reduced truss capacity to set and carry fruits of good size. The fruits are often sun-burnt because of inadequate vine cover. The retarding effect of Cycocel (2-chloroethyl-trimethylammonium chloride; $\mathrm{CCC}$ ) on growth of tomatoes and other plants is well established (Marth, 1963; Liekens et al., 1964; Will, 1966; Klapwijk, 1966). Tomato plants treated with CCC are shorter, sturdier and the leaves turn darker green than those of the untreated plants. Cycocel also enhances root development and promotes drought resistance (Will, 1966). Work with CCC on tomatoes has so far been confined to temperatures normally optimal for growing. The effects of $\mathrm{CCC}$ on tomato growth, flowering and fruiting in relation to temperatures higher than normal are not yet known.

1 This article will also be published as Publication 320, Laboratorium voor Tuinbouwplantenteelt, Landbouwhogeschool, Wageningen, the Netherlands. 
This report is an attempt to define and study the relationship between CCC and growth, flowering and fruiting at high temperatures compared to temperatures normal for tomato growing. The effects of GA on fruiting in relation to high temperature is also briefly examined.

\section{Materials and methods}

Seedlings of the tomato cultivar 'Glory' were raised in a glasshouse at about $20^{\circ} \mathrm{C}$. Three weeks old seedlings were transplanted into 12 inch plastic pots placed in peat on benches. The plants were divided into two groups. One group was kept in a glasshouse at $35^{\circ} \mathrm{C}$ day and $25^{\circ} \mathrm{C}$ night $(12 \mathrm{~h}+12 \mathrm{~h})$. The other group was kept at temperatures normal for tomato growing in the Netherlands, $22^{\circ} \mathrm{C}$ day and $18^{\circ} \mathrm{C}$ night. These two sets of temperatures are hereafter referred to as 'high' and 'normal'. At each of the two sets of temperatures the following treatments were included:

1. Plants left untreated : Control.

2. Artificial vibration of open flowers : Vibration.

3. Cycocel applied to soil two days after transplanting : Eaerly CCC.

4. Cycocel applied to soil at flowering : Late CCC.

5. Dipping first truss in $\mathrm{GA}_{4+7}: \mathrm{GA}$.

In treatments 3 and $4,125 \mathrm{ml}$ of $0.4 \% \mathrm{CCC}$ were applied to the soil in the pots. In treatment $5,50 \mathrm{ppm}$ of $\mathrm{GA}_{4+7}$ were used. The first truss, mostly with 2 to 3 open flowers, was dipped into the GA.

The plants were watered daily. No pruning was made, so all the side shoots remained on the plants. The stem lengths of ten control plants and the CCC-treated plants (early), were measured at intervals of five days for a period of forty days after transplanting, leaf analysis for total and nitrate nitrogen was made at the time of flower opening. Other data included time to flowering, number of flowers, flowers shed, fruits set and fruits developed. Counts of mature fruits weighing more than $20 \mathrm{~g}$ and weights of the first or second fruit were recorded. Seed counts from fruits of 30 to $70 \mathrm{~g}$ being mostly of the first or second fruit were also made. Fifteen fruits were examined in each case. Although additional trusses were allowed to grow, the data collected were confined to the first truss.

Because of failure of plants to set fruits at the high temperature, flowers were handpollinated without emasculation with fresh pollen from plants growing at the normal temperature. In each plant 6 fully open flowers were hand-pollinated. The styles were long enough to be immersed in the pollen, which was visible to the naked eye. Fresh pollen collected from plants growing at the high temperature was used to pollinate another set of plants.

\section{Results and discussion}

Stem height was retarded by $\mathrm{CCC}$ applied both early and late at high and at normal temperature. Fig. 1 shows that the growth rate of the stem is reduced by $\mathrm{CCC}$ to nearly half the normal rate for a limited period following the application of CCC. The plants at the high temperature resumed a non-retarded growth rate 17 days after CCC application.

At the normal temperature, the retarding influence of $\mathrm{CCC}$ persisted longer and was 


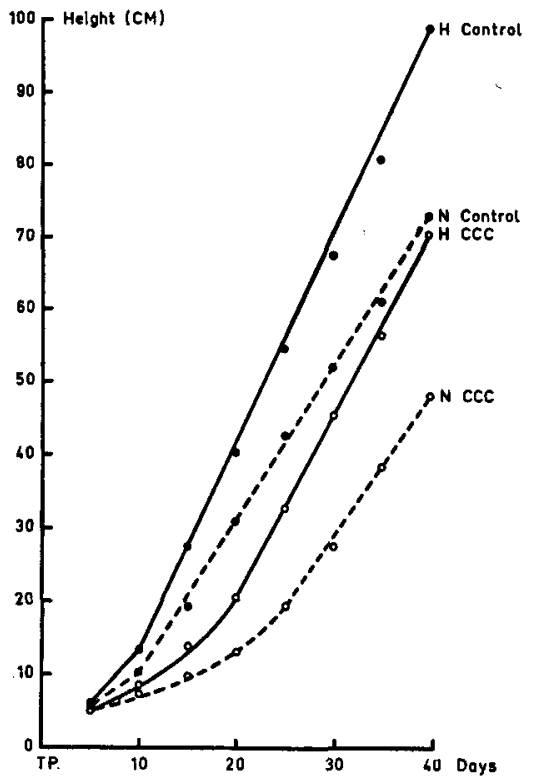

Fig. 1 Stem heights of tomato plants treated with CCC 3 days after transplanting $(T P)$ at high $(H)$ and normal (N) temperatures. CCC applied to soil.

measurable for a period of about 24 days. CCC-treated plants were sturdy with darkgreen leaves. Yellowing and shedding of the lower older leaves were markedly less in the CCC-treated plants compared to the untreated plants at both high and normal temperature.

The CCC-treated plants remained green with a minimum leaf yellowing and shedding till the time of harvest of the fruits in the first truss. This retention of green vine was particularly noticeable at the high temperature.

Tissue nitrogen in plants grown at the high temperature is markedly more than that of plants at the normal temperature (Table 1). Furthermore, CCC-treated plants have more tissue nitrogen than their untreated counterparts at both high and normal temperatures. This is probably due to the bigger and more active root system developed in the CCC-treated plants. Under the circumstances of this experiment it was not possible to make reliable root measurements, but it was decidedly clear that the CCCtreated plants developed a more extensive root system. Will (1966) reported that CCC increases the root system in tomatoes. The ability of the CCC-treated plants to retain

Table 1 Nitrogen level of tomato tissue in relation to temperature and CCC

Treatment Tissue nitrogen (\% dry matter)

Total nitrogen Nitrate nitrogen

High temp.-control

High temp, $+\mathrm{CCC}$

Normal temp.-control

4.09

4.16

1.18

1.38

Normal temp, + $\mathrm{CCC}$

2.95

1.43

0.02

0.54 
Tabie 2 Effect of temperature, CCC and GA on flower shedding and fruit-set in the first truss of the tomato

\begin{tabular}{|c|c|c|c|c|c|c|c|c|}
\hline & \multicolumn{4}{|c|}{ High temperature } & \multicolumn{4}{|c|}{ Normal temperature } \\
\hline & Control & $\begin{array}{l}\text { early } \\
\text { CCC }\end{array}$ & $\begin{array}{l}\text { late } \\
C C C\end{array}$ & $G A$ & Control & $\begin{array}{l}\text { early } \\
\text { CCC }\end{array}$ & $\begin{array}{l}\text { late } \\
\text { CCC }\end{array}$ & $G A$ \\
\hline Number of flowers & 10.4 & 10.0 & 9.8 & 11.0 & 9.8 & 10.4 & 10.0 & 9.2 \\
\hline Flowers shed & 7.2 & 5.8 & 1.0 & 0.5 & 1.0 & 0.5 & 1.0 & 0.5 \\
\hline $\begin{array}{l}\text { Fruits set } \\
\text { (Normal) }\end{array}$ & 0.0 & 0.0 & 0.0 & 7.0 & 7.0 & 6.0 & 7.2 & 6.4 \\
\hline
\end{tabular}

dark-green leaves for a relatively long period is perhaps due to the higher level of tissue nitrogen in these plants.

Time to flowering in the first truss was not influenced by $\mathrm{CCC}$; neither was, as shown in Table 2, the number of flowers. The influences of CCC and GA on flower shedding and fruit-set are also shown in Table 2. When CCC was applied two days after transplanting (early) at the high temperature, more than half of the flowers dropped with no marked difference from the untreated plants. Application of $\mathrm{CCC}$ at the time of visible flower buds (late) reduced flower drop considerably.

Dipping the truss in GA also reduced flower drop. At the normal temperature there was only slight occasional flower drop in all treatments.

At the high temperature, practically all the remaining (not shed) flowers reaching anthesis developed markedly elongated styles often extending for $5 \mathrm{~mm}$ beyond the stamen tube. No fruits were set by these or other flowers. The elongated styles interfered with fruit-set since such flowers set seeded fruits when pollinated by hand. Furthermore the anthers spread one from another with evident uncharacteristic bulging and cracks, a condition very similar to the morphological mutants described as dialytic. The spreading of the stamens disrupts the channels by which the pollen is transferred to the stigma (Mann, 1962). Such flowers are shown in Fig. 2.

Because of these morphological abnormalities in some flower parts at the high temperature, plants failed to set fruits. The cultivar 'Glory' may offer a possibility for use as a male sterile parent in tomato breeding such as breeding for high-temperature

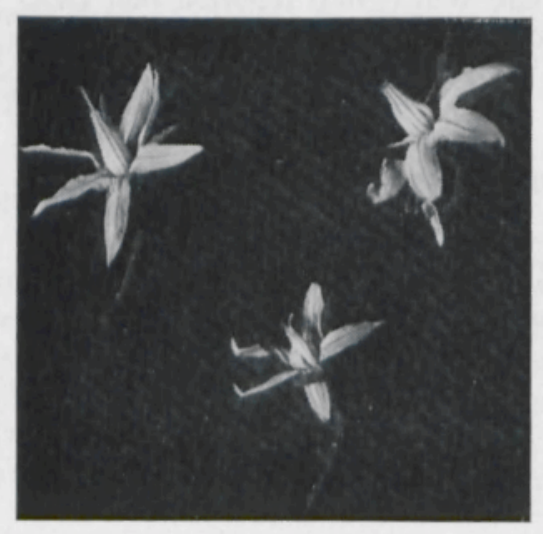

Fig. 2 Some morphological abnormalities in the left hand flowers of plants at high temperature, compared with the normal flower (top right). 
TOMATO: TEMPERATURE, CYCOCEL AND GA

Table 3 Fruit-set in relation to temperature, vibration, CCC and GA

\begin{tabular}{|c|c|c|c|c|c|c|c|c|c|c|}
\hline & \multicolumn{5}{|c|}{ High temperature } & \multicolumn{5}{|c|}{ Normal temperature } \\
\hline & $\begin{array}{l}\text { con- } \\
\text { trol }\end{array}$ & $\begin{array}{l}\text { vibra- } \\
\text { tion }\end{array}$ & $\begin{array}{l}\text { early } \\
C C C\end{array}$ & $\begin{array}{l}\text { late } \\
C C C\end{array}$ & $G A$ & $\begin{array}{l}\text { con- } \\
\text { trol }\end{array}$ & $\begin{array}{l}\text { vibra- } \\
\text { tion }\end{array}$ & $\begin{array}{l}\text { early } \\
C C C\end{array}$ & $\begin{array}{l}\text { late } \\
C C C\end{array}$ & $G A$ \\
\hline $\begin{array}{l}\text { Number of } \\
\text { flowers }\end{array}$ & 12.0 & 10.0 & 11.0 & 11.0 & 10.5 & 10.0 & 10.0 & 11.0 & 10.0 & 9.8 \\
\hline Fruits set & 0.0 & 4.5 & 0.0 & 0.0 & 7.0 & 6.8 & 8.5 & 6.0 & 6.0 & 6.0 \\
\hline $\begin{array}{l}\text { Flowers hand- } \\
\text { pollinated }\end{array}$ & 7.0 & - & 6.5 & 6.0 & - & & & & & \\
\hline $\begin{array}{l}\text { Fruits set } \\
\text { (from hand- } \\
\text { pollinations) }\end{array}$ & 4.5 & - & 3.0 & 5.2 & - & & & & & \\
\hline
\end{tabular}

tolerance. Table 3 shows that late application of CCC at high temperature increased fruit-set only slightly over the control. Both late application and vibration of the flowers gave more fruits than early application of CCC. At the normal temperature, fruit-set was not affected by CCC. Vibration of the flowers at the normal temperature was superior over all other treatments.

Flowers may be retained on the truss with ovaries remaining dormant. The frequency of dormant ovaries is high at high temperature and is particularly noticeable when $\mathrm{CCC}$ was applied late i.e. at the time of visible flower buds of the first truss. This suggests an increased truss capacity to carry fruits if pollination is possible. Evidence in Table 4 from the increase in number of harvested fruits, in fruit weight, and the decreased competitive restriction to the younger fruits on the truss indicates that CCC promotes fruit development probably due to increased tissue nitrogen.

Increased retension of flowers with dormant ovaries resulting from late application of $\mathrm{CCC}$ may also suggest some relationship between the plant auxins or gibberellins in relation to abscission.

Table 4 Mature fruits (>20 g), fruit weight and seed number in relation to temperature, CCC and $G A$

\begin{tabular}{|c|c|c|c|c|c|c|}
\hline & \multicolumn{3}{|c|}{$\begin{array}{l}\text { High temperature } 1 \\
\text { (hand pollination) }\end{array}$} & \multicolumn{3}{|c|}{$\begin{array}{l}\text { Normal temperature } \\
\text { (natural pollination) }\end{array}$} \\
\hline & control & $C C C$ & $G A$ & control & $C C C$ & $G A$ \\
\hline $\begin{array}{l}\text { Number of fruits } \\
(>20 \mathrm{~g})\end{array}$ & 3.0 & 4.5 & 0.0 & 6.0 & 6.2 & 0.0 \\
\hline $\begin{array}{l}\text { Fruit weight } \\
\pm \text { S.D. (g) }\end{array}$ & $39.0 \pm 7.9$ & $49.5 \pm 8.5$ & $14.0 \pm 1.5$ & $55.0 \pm 4.5$ & $52.2 \pm 3.7$ & $15.0 \pm 1.7$ \\
\hline Seed number & $72.0 \pm 33.9$ & $75.0 \pm 30.7$ & 0.0 & $127.0 \pm 21.3$ & $119.0 \pm 20.6$ & 0.0 \\
\hline $\begin{array}{l}\text { Seed number } \\
\text { (high temp. } \\
\text { pollen) }\end{array}$ & $39.0 \pm 20.0$ & & & & & \\
\hline
\end{tabular}

1 Flowers hand-pollinated

Neth. J. agric. Sci. 18 (1970) 
GA increased fruit-set at both temperatures, but the fruits developed remained small and seedless.

However, GA markedly accelerated fruit ripening. The first fruit on the GA-treated truss was ripe ten weeks after seeding. Similar fruits in the untreated trusses were ripe two and three weeks later for high and normal temperature, respectively. When flowers with dormant ovaries were dipped in GA, the ovaries expanded visibly 2 to 3 days later. The fruits thus developed however remained small, non-seeded and hollow, and ripened rapidly.

The number of seeds in the fruit was not influenced by $\mathrm{CCC}$ at either of the temperatures (Table 4). But the seed number was significantly less at the high temperature where the fruits developed from hand pollination. Since the styles were fully immersed in fresh pollen, it is assumed that the maximum number of pollen grains was available to the stigma. The decrease in the number of seeds in fruits at the high temperature is therefore likely to be the result of reduced effectiveness of the pollen at the high tmperature (Abdalla and Verkerk, 1968). Fruits developed from hand pollination with fresh pollen from plants at the high temperature had a lower seed number due to the weakness of the pollen (Table 4).

\section{Acknowledgment}

The stay of the senior author in the Department of Horticulture of the Agricultural University in Wageningen, where this work was done, was made possible though a grant kindly provided by the Netherlands Organization for the Advancement of Pure Science (Z.W.O.). The financial help of Z.W.O. is gratefully acknowledged.

\section{References}

Abdalla, A. A. \& Verkerk, K., 1968. Growth, flowering and fruit-set of the tomato at high temperature. Neth. J. Agric. Sci. 16: 71-76.

Klapwijk, D., 1966. Het effect van CCC op de groei van jonge tomatenplanten. Meded. Dir. Tuinb 29(7): 272-279.

Liekens, H., Vos, J. de \& Godaert, A., 1964. Effect van de groeiremmer CCC op vroege stooktomaat. Tuinbouwberichten $28: 104-105$.

Mann, L. K., 1962. Morphological characteristics affecting reproductive processes in plants. Proc. Pl. Sci. Symp. Campbell Soup Co.: 201-211.

Marth, P. C., 1963. Effect of growth retardants on flowering, fruiting and vegetative growth of holly (llex.). Proc. Am. Soc. hort. Sci. 83: 777-781.

Will, H., 1966. Erste Versuchsergebnisse mit Cycocel zu Tomaten. Gartenbawwissenschaft 31: 115123. 